\title{
Black Female Bodies and Resistance in Gayl Jones Corregidora and Eva's Man
}

\author{
Smrity Sonal ${ }^{1} \&$ Rajni Singh ${ }^{2}$ \\ ${ }^{1}$ Department of Humanities and Social Sciences, IIT (ISM), Dhanbad. Email: \\ smritysonalekkao7@gmail.com \\ ${ }^{2}$ Department of Humanities and Social Sciences, IIT (ISM), Dhanbad. at IIT (ISM), \\ Dhanbad, India. ORCID: oooo-ooo2-1569-8339.Email: rajnisingh18@gmail.com.
}

Received May 12, 2017; Revised July 10, 2017; Accepted July 15, 2017; Published August 11, 2017.

\begin{abstract}
For the black women writers, the body becomes a potent medium for addressing the misrepresentations of the black women in history. It gives them a scope to present the marginalized truths about them and to reappropriate them as subjects. Gayl Jones' writing is also grounded in the black women's experiences. By giving her characters control over their bodies, she gives them a voice to articulate their truths. This article examines the ways in which the black women characters in Jones confront the body, their genetic inheritance, their degradation in history and their memories that have connections with a dark past. There is an attempt to demonstrate how the embodying of the physical self not only gives these women characters the courage to challenge the monolithic representations of black women, but also allows them to reclaim their spaces and to evolve as self-liberated, self-validated women.
\end{abstract}

Keywords: Gayl Jones, Black female bodies, Memories, Resistance, Reclamation.

\section{Introduction: The black female body and its representations}

For the black women writers, the body becomes a potent medium for representing the marginalized truths about them and for renouncing the socially constructed images of black womanhood. In her review of Bennett Michael and Vanessa Dickerson's book, Recovering the Black Female Body: Self-Representations by African American Women Amanda Davis argues that self-representation is the only means to self-evolution in the context of the black women (Davis, 2003). Acting differently from the societal norms governing the female bodies, the coloured female bodies are measured on totally different parameters. The black female body stands for the "the intersection of race and sex" (Nelson, 1995, p. 97). Its unpleasant representations in art, literature, sports, media, or elsewhere can be viewed as what Lisa Collins (2002) calls "product of history, particularly the history of conquest, enslavement, lynching and rape" (p. 99). Moreover, the unpleasant representations of the black female body carry "sensual immediacy" (Brown, 2012, p. 3). Often viewed as "a cipher, remote, alien, distorted and obscured" (Brown, 2012, p. 3), the black women are read in clusters and projected in derogatory ways. Bettina Love (2012) while untying the knots of black womanhood and its proportionality with the body points out "... being a Black woman was more than just having Black skin-it was also about body” (p. 81). For the black women, their bodies become a site of shame that further denounces their physical outlook. Apart from being a storehouse of physical and mental abuses, the body, also becomes a battle ground where the black women are forced to submit themselves to the male supremacy. Under

(C) AesthetixMS 2016. This Open Access article is published under a Creative Commons Attribution Non-Commercial 4.0 International License (http://creativecommons.org/licenses/by-nc/4.0/), which permits non-commercial re-use, distribution, and reproduction in any medium, provided the original work is properly cited. For citation use the DOI. For commercial re-use, please contact editor@rupkatha.com. 
the multi-layered oppressive forces, the black women's "experience of shame and guilt in relation to their bodies and sexuality" (Griffiths, 2006, p. 356) compels them to view their own body as "abnormal, diseased, and ugly" (Griffin, 1996, p. 521).

\section{'Textual healing': A way to self-recovery}

Attempts have been made to re-correct the imaging of the black female bodies by the black women writers who mould and recast these victimized bodies into something new-more desirable and beautiful. Farah J. Griffin (1996) calls these attempts as 'textual healing' that "celebrate black women's bodies in an effort to counter the destructive effects of racialized hierarchies of beauty" (p. 522). Interestingly the black female body shuttle between the extremes of denouncement and appraisals. They signify both "triumph and terror" (Collins, 2002, p. 96). Collins (2002) deconstructs the colored female body saying, "...the Black female body connotes exotica and erotica and serves as an allegory for freedom and its necessary inverse, enslavement" (p. 103). Several black feminist critics have talked about the black female bodies as sites of "desire and repulsion" (Parasecoli, 2007, p. 114), being "dangerous and consuming" (Parasecoli, 2007, p. 114) apart from its being "promiscuous", "expendable" or "sexually deviant" (hooks, 1982). All these markers stand synonymous to the images of Jazebels, Mammy, Sapphire or Hottentot that are indicative of their availability and accessibility (Hobson, 2003 \& hooks, 1982).

In Gayl Jones' exploration of the lives of the black women there is an innate struggle to depict the black "female bodies as sites of healing, pleasure and resistance" (Griffin, 1996, p. 521). In Corregidora (1975) and Eva's Man (1976) she creates protagonists who represent the doubts and fears of black women in general and in a way challenge the reductionist approach towards the black female bodies. The characters, through an inward looking, gauge their excessively submissive and enormously oppressive conditions and try to find the ways of healing the self. The act of inward looking leads them towards self-assertion and identity.

\section{Representation of black female bodies in Jones}

In Corregidora and Eva's Man, Jones stretches the representation of the 'body' from its tangible, physical form to something beyond. She uses these bodies like a 'sponge' or extended 'containers' that soak everything from the past, right from the inheritance of tormenting memories to the gulping of the unseen scars. Battered by the memories, both private and inherited ones, the body becomes a solvent for the characters' tragic past. In Eva's life, memories play "as hard . . . as the present" (Jones, 1987, p. 5), while for Ursa, the past is enrobed in "words"-it is a retelling of "the same story over and over again" (Jones, 1986, p. 11). Memories become a textual narrative that instills 'verdicts' into the bodies and minds of all successive Corregidora women. The overwhelming presence of the past in the lives of the two characters makes them the actual bearers of the brutal history. They not only withstand their own personal pain, but also symbolically represent the pain of their generations. This is why Ursa fails to create a distinct identity of her own. Like Ursa, Eva is also unable to shake off the dominating elements of her personality. She often associates herself with the queen bee and when she is not given the due attention she moves into a state of disillusionment. It is interesting to note the inner psychic turmoil of the two characters. While expressing her intent towards the creation of such neurotic characters, Jones says that she was more interested in the inner self rather than the outer: "I wanted to get the sense of different times and different personalities coexisting in memory" (Tate, 
1979, p. 143). The past subsumes again and again in the lives of Eva and Ursa. This comes in the form of stories and linkages between the daughter-mother-grandmother-great gram. Particularly in the case of Ursa the memories drive her into psychic dissolution. The mother becomes a medium through which Ursa accesses her biological lineage. Her "oral discourse" (Dubey, 1995, p. 252) blurs the boundaries of generations, memories and experiences in the daughters' mind. In doing so, the mother dismantles her daughter's chronological reception of events and her sense of spatial existence. Resultantly, such overlapping of memories "erases" the sense of "difference" in Ursa which is formed due to an "ideological coherence" (Dubey, 1995, p. 253) of experiences. It disrupts her ability to distinguish herself from the others.

Moreover, the body also becomes a vehicle for the transportation of verdicts when oral discourses are accompanied by successive bodily gestures like rubbing of hands over the listener's body in order to affirm the truthfulness of the stories. Great Gram, while narrating stories, vigorously rubbed her hands against Ursa's thighs, as Ursa recalls:

I was on her lap. She had her hands around my waist, and I had my back to her. She would fold them and then unfold them ... and sometimes I'd see the sweat in her palms ... Once when she was talking, she started rubbing my thighs with her hands, and I could feel the sweat on my legs. Then she caught herself, and stopped, and held my waist again (Jones, 1986, p. 11).

Such physical gestures not only affirm the validity of the verdicts, but also affect the listener deeply. Commanding the listener's physical involvement, such narrations most of the time lead to their failure to distinguish their scar-free bodies from the violated bodies of their inherent storytellers. Such bodily gestures somewhat hypnotize the listener. They, in an amplified degree, begin to intensify the storytellers pain assuming it to be their own private one and start descending to what Maria Root calls an "insidious trauma", which "functions as an ancestral subtext to their own lives" (Milatovic, 2014, p. 1). It is believed that such trauma hinders the process of healing in the victim. Even, gestures like slapping the listener or giving her a "real hateful look" (Jones, 1986, p. 61) on her questioning or expression of doubts on the validity of the verdicts, forcefully "commands the daughter's unqualified acceptance" (Dubey, 1995, p. 253) of the unacknowledged evidences. Such bodily gestures reveal the storyteller's conserved anguish against their culprit. Also, these bodies, while in the process of grabbing, rubbing or vocally transmitting the verdicts to their successive listeners, implicitly perform an act of bodily resistance that is also transmitted to them along with the stories. Though these stories traumatize the listener's minds in the in the initial stages yet they eventually make their bodies aware and resistive towards their wrongdoers. Such narratives about the violated bodies not only signify the act of resistance, but also correspond to the process of healing of the victimized body. Griffin (1996) while discussing the various ways of healing the violated black women's bodies, considers, the story telling act as one of the powerful means of healing among these women. Further, she says, “... the author's storytelling, like the character's remembering, acts as a means of confronting the legacy of slavery and re-imagining a different future for their characters and for the readers as well. They perform a textual healing." (Griffin, 1996, p. 527)

In both the novels, the characters' minds and bodies are entangled within the mesh of the unpleasant personal experiences and traumatic memories of their tragic past. Resultantly, they fail to distinguish between the boundaries of space and time. Regarding such chronological disruption that leads to one's ambiguous existence, Jones says, "Time has little chronological sequence, and the characters seem to coalesce into one personality" (Tate, 1979, p. 146). Failing to sense their existence on physical grounds and feeling psychologically dislocated, these women 
most of the time descend into some sort of an eternal mental illness. In Eva's Man, Eva is projected as a mad woman for her verbal failure to justify her crime of poisoning, castrating and killing of Davis Carter. Nobody cares to view her action on the parameters of a cause-and-effect relation which forces her to take "justice into her own hands" (Lionnet, 1993, p. 135). Also, her childhood and adolescence are witnessed as "a series of sordid, dehumanizing sexual encounters" (Ward, 1982, p. 100) by her close ones including her own cousin, her mother's boyfriend, uncle or other acquaintances, as frequently as by strangers, which keeps adding to the character's psychological complexities. She is disintegrated on several grounds "as a whore, as crazy, or as the victim of a deceitful lover" (Sweeney, 2004, p. 458). Eva can also be analyzed on Fanon's perception of 'third person consciousness', which, as Nadege Clitandre (2001) unfolds it as the "act of stepping outside of oneself to view one's image in the eyes of the oppressor" (p. 35) until the subject "eventually gains the perception of his oppressor" (p. 35). Such presumptions of the oppressors regarding the victim, continuously demeans her self-respect, making her surrender to the conferred abstractions of the oppressor. Eva's self-imaging as a 'whore' reflects on the fact that how "men perceive women actually define their characters" (Tate, 1979, p. 146). Despite such presumptions, she does not succumb to the oppressive forces around her. She takes a bold step and exhibits the courage to look into the self and its relation with the external world with a greater insight. Thus the deformed body of Eva acquires a powerful stature. It not only surpasses the abilities of a normal being, but also exercises authority over what it had previously surrendered to, the dominions of space and time. Similarly Ursa's infertile body reclaims an independent existence and refuses to "transmit the legacy of slavery to future generations" (Hine and Wittenstein, 1981, as cited in Dubey, 1995, p. 246). Ursa undergoes traumatic experiences due to her barrenness but she succeeds in overcoming those by erasing "traces of a painful matrilineage" (Griffiths, 2006, p. 361).

Ursa's unproductive body, that inscribed the blues within itself and Eva's fragile body, are engaged in a continuous conflict with their complexities and doubts. Ursa allows her body to celebrate and resists her confinement through her songs and monologues: "I am Ursa Corregidora. I have tears for eyes. I was made to touch the past at an early age. I found it on my mother's tiddies. In her milk. Let no one pollute my music. I will dig out their temples. I will pluck out their eyes" (Jones, 1986, p. 77). On the contrary, Eva speaks through her silence. Several critics have viewed the silence of Eva as an empowering act (Basu, 1996 \& Sweeney, 2004). Jones, too, commenting on Eva's silence says "controlling what she will and will not tell is a way of maintaining her autonomy. Her silences are also ways of maintaining this autonomy” (Tate, p. 146-47). Also, Eva's silence "foregrounds the act of remaining receptive" (Sweeney, 2004, p. 459) thereby enhancing her physical and sensual receptivity, where silence becomes "an act of attentive listening, forestalls mastery and the immediate imposition of certain meaning, and draws attention to instances when existing explanations fail" (Sweeney, 2004, p. 458). Megan Sweeney (2004) believes that the silences imposed upon women become an essential tool in understanding the self "for coming to terms with the many roles that silence has played in their lives; and for situating themselves in relation to discourses about victimization and resistance" (Sweeney, 2004, p. 459).

If body is a text for cultural inscriptions and a locus of social control, it also acquires a prime role in the process of healing. Talking about the process of healing in the black female bodies that undergo racist and sexist atrocities, Camille Passalacqua (2010) writes, "The black female bodies are positioned initially as the suffering center of familial past rooted in slavery, yet what is more significant is that these narratives explore the ways in which these same bodies become something new" (p. 139). She points at the magical touch of the narratives that work as a 
healing balm in the lives of the black women. These narratives or stories help in representing and reconstructing the bodies into something new. Such kind of reconciliation encourages the characters' entry into "an internal personal struggle" (Passalacqua, 2010, p. 139) with themselves that leads them to the "rearrangement with the external world" (Passalacqua, 2010, p. 139). Memories become a trope to interrogate the self. It provides a ground for "integration of the traumatic past with the present self" (Passalacqua, 2010, p. 139). Thus the body transforms from the dwelling house of pain and deformed identity to a state of reunification with the mind which results in "recuperation and healing from trauma" (Passalacqua, 2010, p. 139):

For healing to begin, there must be a revalorization of the flesh that recognizes and allows for a reunification of the body and the mind, expressed through a language of the body ... This also requires accepting the body in its new form-a form that carries scars in its flesh, just as the mind carries its own scars in the form of memories of violence (Passalacqua, 2010, p. 140).

What Passalacqua suggests can be found in Ursa and Eva when they tend to accept their bodies in its new form. Ursa's hysterectomy initially repels her to accept her new body. Right from her childhood she is taught that she possesses the womb which is meant for producing generations. When she discovers the dis-functioning of her womb, a shard of memory brings to her, her mother's conversation: "Honey, I remember when you was a warm seed inside me, but I tried not to bruise you. Don't bruise any of your seeds. I won't, Mama" (Jones, 1986, p. 41). This memory shatters her essence. She feels "as if something more than the womb had been taken out" (Jones, 1986, p. 6). The trauma of not being able to reproduce does not evade easily. Healing begins only when she accepts her new body and desires a release from history:

History affects Ursa's personality-the history of the women before her-their conflicts, frustrations, etc. She wants to make sense of that history ... She doesn't want to be bound by that history . . . she doesn't want to be told by those women and their Corregidora stories how she must feel about the past" (Rowell, 1982, p. 45).

Ursa's infertility provides her a release from the claptraps of history. She is free from the normative roles of reproduction and motherhood. Her hysterectomy allows her to participate in "her quest for a new identity that can compensate for her lack of womb" (Dubey, 1995, p. 251). Ursa's struggle with her body's deformity gradually provides her the courage "to transcend history and to create a new story for herself" (Dubey, 1995, p. 252). However, the burden of the female body continues to generate the bodily conflict in Ursa where she cannot deny the fact that she is a woman and at least "got the hole" (Jones, 1986, p. 41). The thought of owning a female body arouses the female desires and compels her to indulge with the self.

Eva too struggles to accept her body with all its scars. Her progression towards resistance and healing is witnessed through her, "struggle for the control" (Lionnet, 1993, p. 135) of her own body that "determines the ultimate act of resistance and survival" (Lionnet, 1993, p. 135). On the self-asserting roles of female bodies, Jennifer Griffiths (2006) suggests the supportive role of "illness" or "accident" in the lives of Jones' characters, both Eva and Ursa. She asserts that the two challenging phases-illness and accident-"indicate a period of transformation and transition" (p. 354) within the victims, thereby 'giving voice' to their past which is self-liberating. Eva's "process of acting out" (Griffiths, 2006, p. 354) through the castration of Davis offers a kind of poetic justice to all the women who have encountered sexual victimization and were throughout "silenced in their families, in their communities, and in the justice system" (Sweeney, 2004, p. 465) failing to "voice their victimization" (Sweeney, 2004, p. 465). Transforming her rage into action, Eva also becomes an extended character of Ursa. Jones reveals, "Eva carries out what Ursa 
might have done, but didn't" (Rowell, 1982, p. 48). Ursa's control over her body restrains her from committing what Eva did due to her impulsive drive.

\section{'Vagina Dentata': A play of desire and resistance}

Several feminist critics have talked about the vagina being a site of both desire and resistance. The female though posing sexuality, also instills fear in the minds of men which has given vent to the term 'Vagina Dentata', that implies "vagina-with-teeth" (Raitt, 1980, p. 415). Analyzing the graphical connotations of Rene's De Voil, depicting the replacement of a woman's mouth with her genitals, Greeley asserts, "She no longer speaks with words; if indeed she speaks at all it is through her sexual anatomy" (Greeley, 1992, p. 48). Contrasting the patriarchal nature of temporal proactiveness only during the act of sexual performance, a woman continues to feel it much beyond, allowing it to transcend deep into her inner self. Sex thus becomes a "metaphor" (Rowell, 1982, p. 46) in the novels of Jones. It is studied on both tangible physical grounds as well as on the character's psychological level. Also, for the two characters, sex is not a constant entity. It is both fascinating as well as horrifying at the same time. This intermingling of 'desire' with 'fear', 'real' with the 'imaginary', 'present' with the 'past' and the 'personal' with the 'other' in the characters' analysis of their sexual engagements leads to a chaos within themselves. This chaos may result from one's incapability in remembering the actual order of events, to the overlapping of memories, to the inability to distinguish between the pleasant and unpleasant sexual experiences. Eva fails to distinguish between her "sexual entrapment" (Sweeney, 2004, 457) and "sexual desire" (Sweeney, 2004, 457). While expressing her carnal desires in the jail she mixes up her "Breath and sweat and desire" (Jones, 1987, 154) and says, "I wanted to be fucked again" (Jones, 1987, 154). Gripped in her bodily desires she further says: "I wanted to make music, hard, deep, with my breath, my tongue inside his mouth. I thought of undoing his trousers, making gestures with my tongue, gestures he'd understand, and then his hands would go into my panties, between my legs and ass" (Jones, 1987, 155). Commenting on textual healing of the black female bodies, Griffin (1996) considers "the erotic" to be "an important ... site of reclamation for black women" (p. 526), where it is also seen as a "foundation for resistance" (p. 526). This erotic is witnessed in Eva's carnal desires and her sex act in jail. Her physical engagement with one of the prisoners, reflect the significance of this erotic, where such carnal needs, fed by the homosexual lesbian relationships reform a black women's body from its "ugly and undesirable" (Griffin, 1996, p. 529) state to something more desirable and beautiful. The erotic become a means to an orgasmic gratification for the self. Orgasm here is viewed as "a site of agency . . . a moment of selfimmersion ... a space beyond the control of a master" (Griffin, 1996, p. 528), it becomes a "... the space where the body loses control over itself . . . and as such eschews control of any kind" (Griffin, 1996, p. 528). The erotic desires of the suppressed female bodies pave a way for releasing oneself from the "material conditions and surroundings while also claiming her physical self" (Griffin, 1996, p. 529). Jones also associates the element of the 'orgasmic' with those of food and edibles. Davis' analysis of Eva's way of eating is associated with the act of love making. Also the reduction of Eva's body into 'sweet meat', or her breasts being synonymous to 'loaves of bread' stirs the idea of the "edible female body" (Parasecoli, 2007, p. 112). While orgasm empowers the sick bodies of black women resisting ugliness and undesirability, the feminine custom of menstruation on the other hand affirms to this bodily resistance (Davison, 1995, p. 401). Eva's menstruating body keeps Davis away from exercising his control over her. Her sexual complexities empower her with physical capabilities. She thinks of herself like a queen bee or a 'river' that swallows all her lovers (Jones, 1987, p. 142). Commenting on the bee image of Eva, Jerry W. Ward 
(1982) says she is "the kind of woman who "kills" every man with whom she is intimate" (p. 101). Eva assumes that her body is that of the queen bee that has the power to seduce. She also believes that she is the new Medusa, different from the mythical one-more destructive and more powerful- "I'm Medusa, I was thinking. Men look at me and get hard-ons. I turn their dicks to stone. I laughed. I'm a lion woman" (Jones, 1987, p. 130). Eva's act of relating herself to that of 'queen bee' and 'mad Medusa' reflects the characters outrageous approach to challenge her oppressors. She does not accept those identity markers that put her in submissive frames; rather she chooses a notorious marker for herself-mad Medusa. This Medusa embodies wildness of a different kind because she does not want to separate herself from her actual mad image which was tagged to her body. Thus the embracing of her madness in the form of a prefix depicts her self-acceptance that eventually empowers her to assert her individuality. The sexual experiences of Ursa, on the other hand, can be examined on both physical and psychological planes. The character's sexual experiences with her husband Mutt and Tadpole lies contrary to her imaginary, unpleasant sexual experiences of her familial matrilineage. Ursa's bodily complexities "threatens her psychic integrity" (Griffiths, 2006, p. 360). Further, her fear of sexual intimacies with Corregidora is illustrated through her dreams that were as real as she could feel the penetration of a 'stiff penis inside'. Commanding one's submission, the forced sexual act according to Clitandre (2001) is the oppressor's "ability to reduce the body to flesh" (p. 33) and to also gain "control over the body's voice and pain" (p. 33). Ursa and Eva's continuous resistance through their thoughts, dreams, monologues, sexual performances, menstruation or experiencing the erotic through imaginary reminiscences hinders their oppressors' attempts to gain control over their bodies. It performs a ritualistic act of resistance and healing for these women. Ursa's approach in experiencing their pain is more than just being sympathetic, something that even moves beyond the empathetic, due to the traumatic behaviour called "insidious trauma". Unlike the sexualities of the black males, who have a unidirectional approach towards sex pertaining to the element of 'pleasure' as the means to outlet their long condensed rage resulting from racial discriminations or their masculine ambiguities, the Ursa and Eva have a two way approach of both pleasure symbolizing freedom or relief as well as pain symbolizing enslavement or bondage. Such duality resists their activeness and full participation in the sexual activity, where their bodies reside in the present world while the mind keeps travelling back in time. Amidst such delusions, the black women confront their sexuality by celebrating their uniqueness, wildness, or madness that generates a desire to love the self.

\section{Conclusion}

Narratives about women largely deal with their fight against formidable odds and their responses to the cultural stereotyping. "A woman without a body" (Cixous, 1976, p. 880) remains "dumb" (Cixous, 1976, p. 880) and "blind" (Cixous, 1976, p. 880) to her external world and therefore, "can't possibly be a good fighter" (Cixous, 1976, p. 880). While writing about the experiences of the black women, Jones touches upon the larger black feminine sensibilities. She narrates the lives of these women with a purpose- to legitimize their female self, its history and culture. In the process of unraveling the hidden histories of the characters, she invents a new poetics. She re-appropriates them as subjects, who reclaim their control over their bodies and with a voice of their own, speak about themselves. The body in Jones becomes a metaphor; a text stratifying inter-textual layers that corresponds to the multiplicity of voice suppressed within these mutilated black bodies. It encapsulates within itself the multiple narratives of marginalization and oppression. Jones, through her characters, voices the black female subjectivity and their desire to liberate 
themselves. While asserting the self, the characters speak beyond the delimitations of language. They speak through their bodies and retaliate through their memories, silence, monologues and sexuality. Through Ursa and Eva, Jones suggests 'self-acceptance' and 'celebrating the difference' to be the powerful means to alleviation and reconciliation with the self. She empowers the battered bodies of her characters converting them into sites of resistance and healing. The black violated bodies of Ursa and Eva become a power matrix through which they proclaim their resistance, heal up and move towards the celebration of the self. Their renewed knowledge of the self helps them in realizing their shift from the object to subject position.

\section{References}

Basu, B. (1996). Public and Private Discourses and the Black Female Subject: Gayl Jones' 'Eva's Man”. Callaloo, 19(1), 193-208. doi: 10.1353/cal.1996.ooo1.

Brown, C. (2012). The Black Female Body in American Literature and Art: Performing Identity. New York: Routledge.

Cixous, H., Cohen, K., \& Cohen, P. (1976). The Laugh of the Medusa. Signs: Journal of Women in Culture and Society, 1(4), 875-893. https://doi.org/10.1086/493306

Clitandre, N. (2001). Body and Voice as Sites of Oppression: The Psychological Condition of the Displaced Post-colonial Haitian Subject in Edwidge Danticat's “The Farming of Bones”. Journal of Haitian Studies, 7(2), 28-49. Retrieved December 10, 2016 from http://www.jstor.org/stable/41715099

Collins, L. (2002). Economies of the Flesh: Representing the Black Female Body in Art. In K. W. Sanders (Ed.), Skin Deep, Spirit Strong: The Black Female Body in American Culture. U.S.A: University of Michigan Press. pp. 99-127

Davis, A. (2003). Review [Review of the book Recovering the Black Female Body: Self Representations by African American Women, by M. Bennett and V. D. Dickerson (Eds.)]. Feminist Teacher, 14(3), 266 267. Retrieved December 05, 2016 from http://www.jstor.org/stable/40545898

Davison, C. M. (1995). “Love'em and Lynch'em”: The Castration Motif in Gayl Jones's Eva's Man. African American Review, 29(3), 393-410. doi:10.2307/3042390

Dubey, M. (1995). Gayl Jones and the Matrilineal Metaphor of Tradition. Signs: Journal of Women in Culture and Society, 2o(2), 245-267. doi:10.1086/494974

Greeley, R. A. (1992). Image, Text and the Female Body: René Magritte and the Surrealist Publications. Oxford Art Journal, 15(2), 48-57. Retrieved January 28, 2015 from http://www.jstor.org/stable/1360500

Griffin, F. J. (1996). Textual Healing: Claiming Black Women's Bodies, the Erotic and Resistance in Contemporary Novels of Slavery. Callaloo, 19(2), 519-536. Retrieved February 27, 2017 from http://www.jstor.org/stable/3299218

Griffiths, J. (2006). Uncanny Spaces: Trauma, Cultural Memory, and the Female Body in Gayl Jones's "Corregidora” And Maxine Hong Kingston's “The Woman Warrior". Studies in the Novel, 38(3), 353 370. Retrieved August 29, 2016 from http://www.jstor.org/stable/29533769

Hobson, J. (2003). The "batty" politic: Toward an Aesthetic of the Black Female Body. Hypatia, 18(4), 87-105. Retrieved December 05, 2016 from http://www.jstor.org/stable/3810976

hooks, b. (1982). Ain't I A Woman: Black Women and Feminism. Boston: South End Press.

Jones, G. (1986). Corregidora. Boston: Beacon Press.

Jones, G. (1987). Eva's Man. Boston: Beacon Press. 
Lionnet, F. (1993). Geographies of Pain: Captive Bodies and Violent Acts in the Fictions of Myriam Warner Vieyra, Gayl Jones, and Bessie Head. Callaloo, 16(1), 132-152. Retrieved August 29, 2016 from http://www.jstor.org/stable/2931822

Love, B. L. (2012). Chapter Six: Body Image, Relationships, Desirability, and Ass. Counterpoints, 399, 78-87. Retrieved December 05, 2016 from http://www.jstor.org/stable/42981581

Milatovic, M. (2014). Cycles of Violence: Ancestral Subtexts in Gayl Jones' Corregidora. Postcolonial Text, 9(2), 1-19.

Nelson, C. (1995). Coloured Nude: Fetishization, Disguise, Dichotomy. RACAR: revue d'art canadienne / Canadian Art Review, 22(1/2), 97-107. Retrieved December 05, 2016 from http://www.jstor.org/stable/42630539

Parasecoli, F. (2007). Bootylicious: Food and the Female Body in Contemporary Black Pop Culture. Women's Studies Quarterly, 35(1/2), 110-125. Retrieved December 05, 2016 from http://www.jstor.org/stable/27649657

Passalacqua, C. (2010). Witnessing to Heal the Self in Gayl Jones's “Corregidora” and Phyllis Alesia Perry's "Stigmata". MELUS: Multi-Ethnic Literature of the US, 35(4), 139-163. Retrieved July, o6, 2016 from http://www.jstor.org/stable/2575956

Raitt, J. (1980). The "Vagina Dentata" and the "Immaculatus Uterus Divini Fontis". Journal of the American Academy of Religion, 48(3), 415-431. Retrieved June, 15, 2017 from http://www.jstor.org/stable/1462869

Rowell, C. H. (1982, October). An Interview with Gayl Jones. Callaloo (16), 32-53. doi:10.2307/3043967

Sweeney, M. (2004). Prison Narratives, Narrative Prisons: Incarcerated Women Reading Gayl Jones's “Eva's Man”. Feminist Studies, 30(2), 456-482. doi:10.2307/20458975

Tate, C. C. (1979, December). An Interview with Gayl Jones. Black American Literature Forum, 13(4), 142-184. Retrieved August 29, 2016 from http://www.jstor.org/stable/3041481

Ward, J. W. (1982). Escape from Trublem: The Fiction of Gayl Jones. Callaloo (16), 95-104. doi:10.2307/3043975 